\title{
Steep wall mining: engineered structures used in the management of rockfall hazards at Kanmantoo copper mine
}

\author{
BJ Hutchison Hillgrove Resources Ltd, Australia \\ AT Morrison Geobrugg Australia Pty Ltd, Australia \\ DS Lucas Mining One Pty Ltd, Australia
}

\begin{abstract}
The Kanmantoo Copper Mine in the Adelaide Hills of South Australia was operated by Hillgrove Resources Limited from 2010-2019. This was a steep-walled, $360 \mathrm{~m}$ deep, open pit mine that required an extensive rockfall management plan and the installation of significant rock support and rockfall mitigation measures. The adoption of these systems allowed inter-ramp angles of the structurally controlled west wall to be steepened from 45 to $57^{\circ}$, over a height of $300 \mathrm{~m}$.

This paper describes the various methods utilised to manage a range of rockfall hazards experienced at the mine including the use of shear pins, drape mesh, attenuator fences, low-and high-energy rock catch fences and mesh/cable strapping.

The design, construction methods, associated costs and the performance of the various engineering controls are described.

Keywords: rockfall, steep mining, rock support

\section{Introduction}

Hillgrove Resources Limited (HGO) undertook open pit mining operations at the Kanmantoo Copper Mine from 2010 to 2019. These operations involved a series of cutbacks (Spitfire, Kavanagh, and Giant) of the original 1970's Kanmantoo pit; as well as two satellite pits (Nugent and Emily Star). The progressive development of the cutbacks and pits provided an opportunity to gather geotechnical information and to trial steep wall designs prior to their implementation in the final Giant Pit cutback. The largest risk of the adopted Giant Pit steep wall design was deemed to be rockfall. To reduce rockfall risk, HGO applied a series of safe operating procedures and a variety of engineering solutions to prevent and/or control rockfalls. This paper discusses the design characteristics, the construction aspects and costs of the engineering components used to control and/or reduce the risks from rockfall.
\end{abstract}

\section{$2 \quad$ Giant pit steep wall design}

The details behind the assessment and adoption of the steep wall design of the Giant Pit cutback are described in Hutchison et al. (2017). The adopted slope configuration can be seen in Figure 1. The first line of defence against rockfall is the maintenance of adequate berm widths to provide catch capacity. HGO had compiled an extensive rockfall database (Hutchison et al. 2015) that showed that $97 \%$ of rockfalls came to rest within $10 \mathrm{~m}$ of the toe of the batter on the working floor. The vast majority of these rockfalls were less than $500 \mathrm{~kg}$. Based on the runout data, the berm width was set at $11.5 \mathrm{~m}$ to allow some crest loss. More importantly, it was well known that extensive crest loss occurred on the west wall of the previous cutbacks due to the existence of $35-45^{\circ}$ easterly dipping joints (J1 joints). Based on experiences from the Savage River and Koolan Island open pit mines, the lead author instigated trials of shear pinning, in similar rock conditions in the adjacent Nugent Pit. Following those successful trials in preventing large planar and wedge failures and the reduction in crest loss, shear pinning of all western berms was adopted. This was subsequently extended 
to the lower east wall where the main ramp system reduced down to single lane traffic. Although crest loss in such conditions was not as prevalent in the previous cutbacks, it was deemed prudent to ensure access was maintained in the single lane conditions.

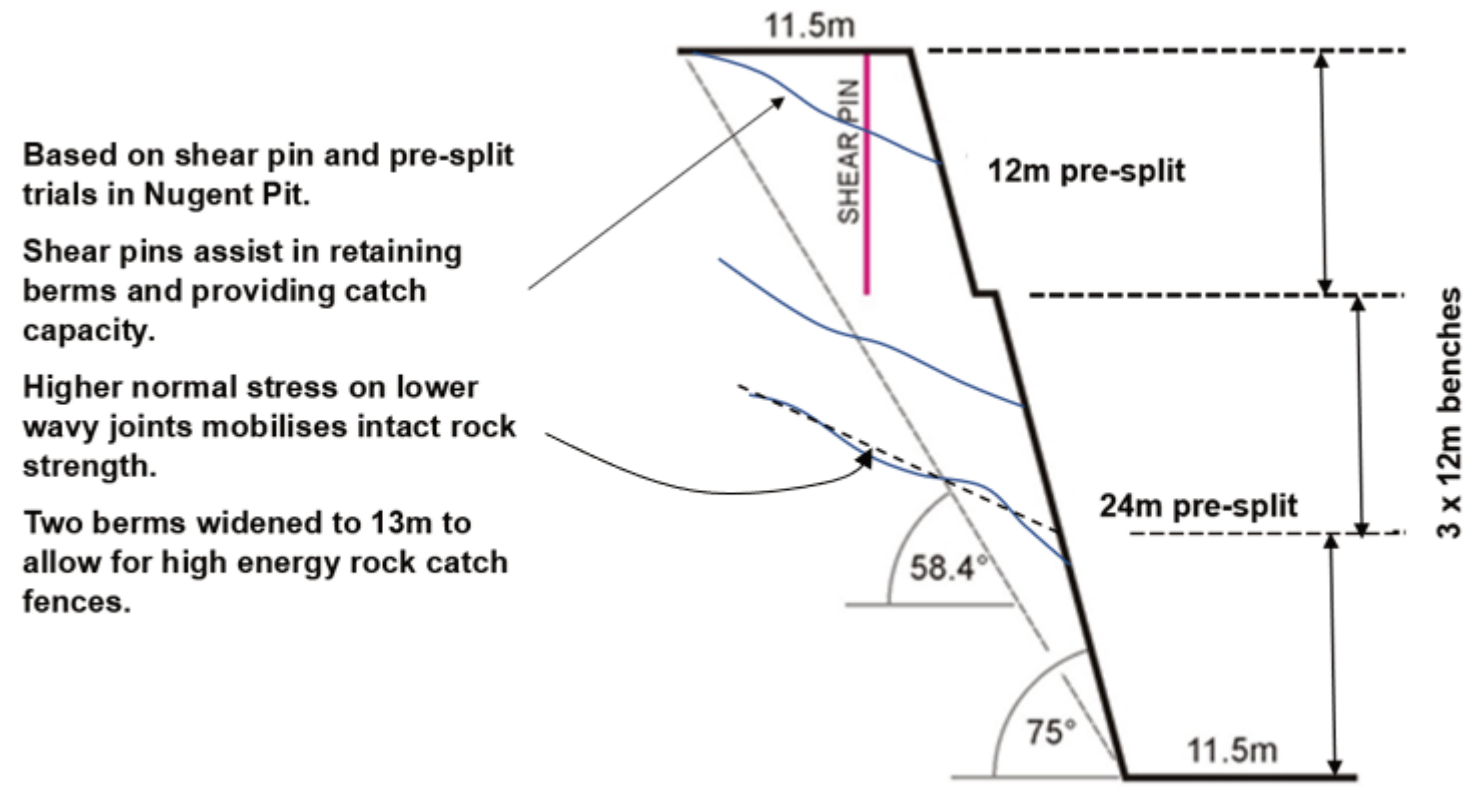

Figure 1 West wall slope configuration

Another feature of the steep wall design was the adoption of $36 \mathrm{~m}$ high batters. Such batters would allow any rockfall from high up on the batter to gain significant levels of kinetic energy, especially if a rock was not contained on and overflew a catch berm. To mitigate against such circumstances, three berms spaced about $108 \mathrm{~m}$ vertically apart (RL 1190, RL 1082 and RL 908) were widened to $13 \mathrm{~m}$ to accommodate high-energy rock catch fences.

The resultant design-with the three widened berms for the fences and a subsequent flattening of the lower $36 \mathrm{~m}$ batter to $60^{\circ}$-increased the west wall inter slope angle from 45 to $57^{\circ}$, over a height of $300 \mathrm{~m}$.

\section{Shear pin design and installation}

The lead author's previous experience in shear pinning utilised used railway line as the pin. This required a 300-350 mm diameter drillhole to allow concrete to be poured around the pin. At Kanmantoo, the maximum diameter hole that could be drilled by the available Atlas Copco L8 rigs was $210 \mathrm{~mm}$. The shear pin material adopted was $12 \mathrm{~m}$ long, $100 \mathrm{~mm} \times 100 \mathrm{~mm} \times 9 \mathrm{~mm}$ rectangular section grade 350/450 steel. The steel pins were lowered into the drill holes by crane. The pins had two $0.5 \mathrm{~m}$ long slots cut on opposite sides $1 \mathrm{~m}$ up from the base of the pin and then a third slot was placed $6 \mathrm{~m}$ up from the base, refer to Figure 2 . The pins were grouted in place using a $32 \mathrm{MPa} 75 \%$ sand $-25 \%$ cement grout mix delivered to site by agitator trucks. The grout mix was directed down the centre of the pin. As it emerged from the bottom slots any water in the base was displaced up the drillhole. The middle slot was required when there were significant amounts of groundwater.

The shear pins were typically drilled $1.5-1.7 \mathrm{~m}$ apart and $1.5 \mathrm{~m}$ behind the design crest. Theoretically, the pins were only required to be $2 \mathrm{~m}$ apart to provide stability against planar failures along the $\mathrm{J} 1$ joints. The pins were initially trialled at the $2 \mathrm{~m}$ spacing but in practice, the closer spacing was required due to the blockiness of the rock mass.

Shear pin installations along ramp crests required the initial ramp shot to be widened enough to allow for pre-splitting and a trim shot. Once the widened ramp shot was cleaned off, the shear pins were then drilled and installed from ramp grade. Typically, a minimum of 24 hours was allowed for the grout to set before taking the pre-split shot in front of the pins. 


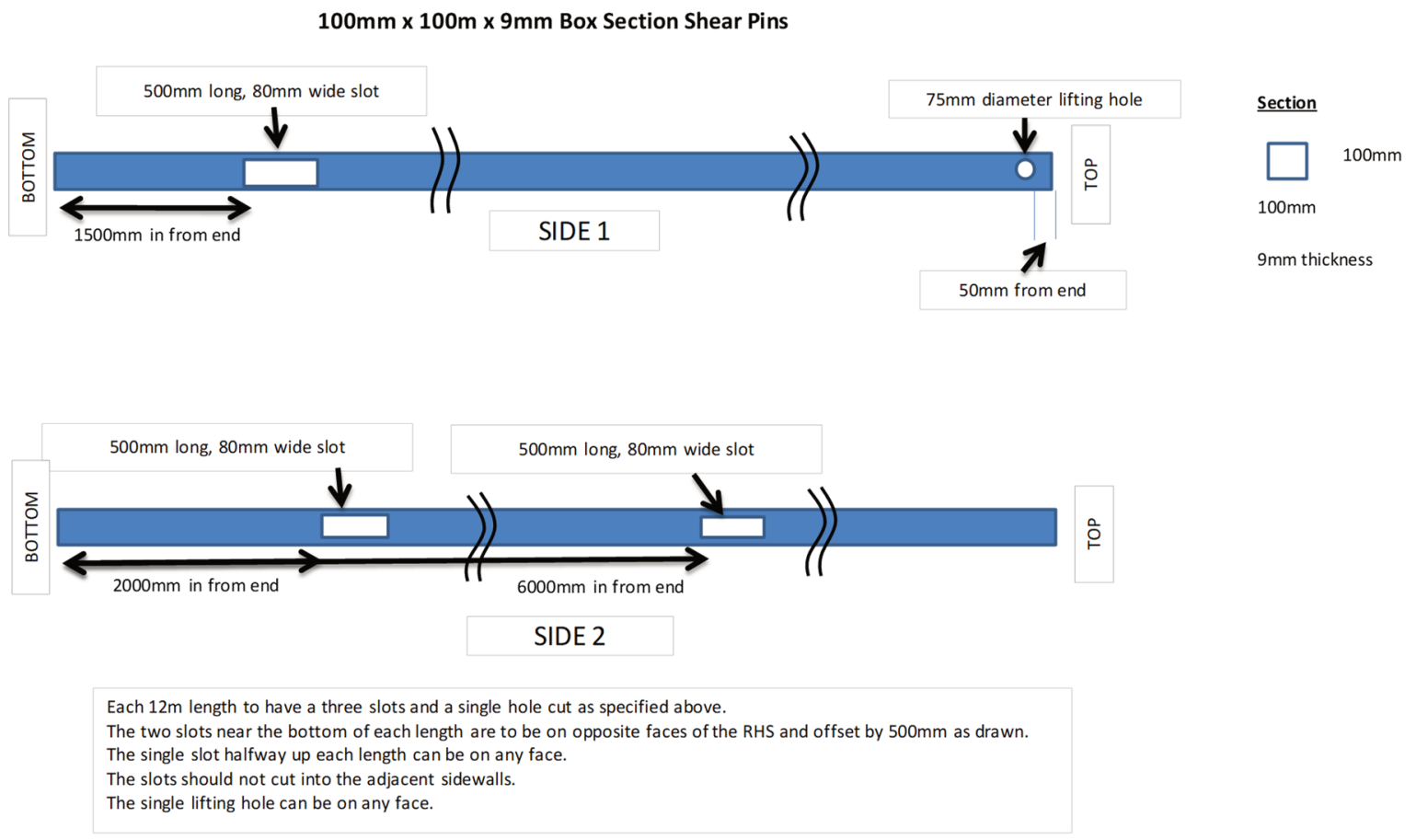

Figure 2 Shear pin details

\section{Shotcrete}

On three occasions, shotcrete was applied to highly fractured crest areas. These works were carried out by an outside contractor and provided excellent results. However, due to the local contractors' civil works commitments and difficulties in scheduling them into the mine sequence, it proved much easier to use drape mesh installations to deal with the risks of highly fractured crest areas.

\section{$5 \quad$ Engineered rockfall control structures}

Rock catch fences, drape meshes, cable straps and attenuator fences were installed in multiple locations around the Giant Pit. The designs and materials for the various structures were supplied by Geobrugg Australia. The designs required the following input parameters from the site geotechnical department:

- Rock block size.

- Rock block shape.

- Density.

- Slope profile.

- Barrier and expected rockfall source locations.

Wherever possible laser scanners were used to provide true profiles of the slopes rather than using design profiles. Geobrugg typically used RocFall software (Rocscience 2018) to assist in the design of the rockfall barriers. Hillgrove's rockfall database was used to set the first two parameters and to assist in the calibration process by allowing input parameters to be adjusted to mimic the typical rockfall runout data.

\subsection{Rock catch fences}

\subsubsection{High-energy rock catch fences}

Two relatively long 3,000 kJ rock catch fences were installed on the RL 1180 and RL 1008 levels ( $293 \mathrm{~m}$ and $500 \mathrm{~m}$ respectively). The fences were designed to capture multiple hits of $20 \mathrm{t}$ blocks originating $36 \mathrm{~m}$ higher 
up. The upper fence (Figure 3) was designed with the Rocco mesh on the downhill side of posts. Following the blasting of the trim shots back to the design crest, the RL1180 fence was left with gaps between the base of the fence and the berm in several locations, as can be seen in Figure 3. In two locations, localised crest loss required additional bench mesh to be retro-fitted. In one area, the gap was quite extensive and could not be remediated so an additional $44 \mathrm{~m}$ long section of fence was then constructed on the underlying RL1052 berm.

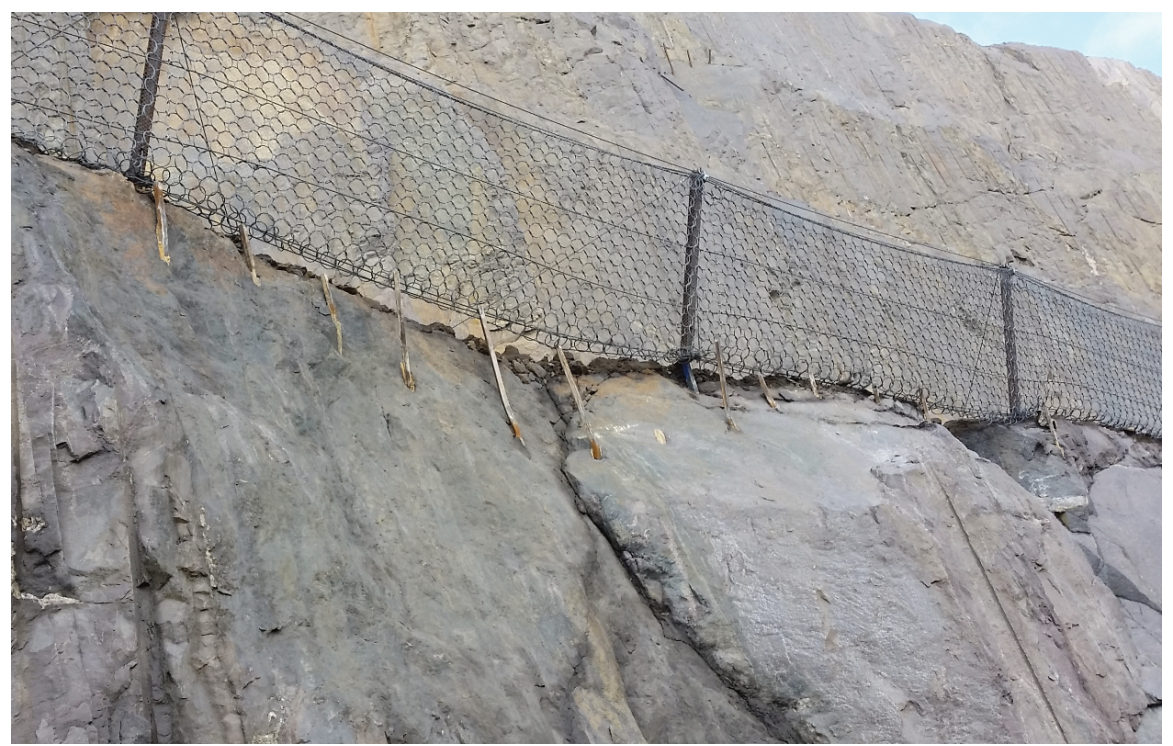

Figure 3 Geobrugg RXE 3000 A barrier

Geobrugg was then asked to provide an alternative design that placed the mesh inside the posts and anchored about half the way back across the berm (Figure 4). This design was adopted for the RL 1008 berm installation. Although there were additional costs associated with improved design, these were offset by not requiring any remedial works, as is discussed later in the paper.

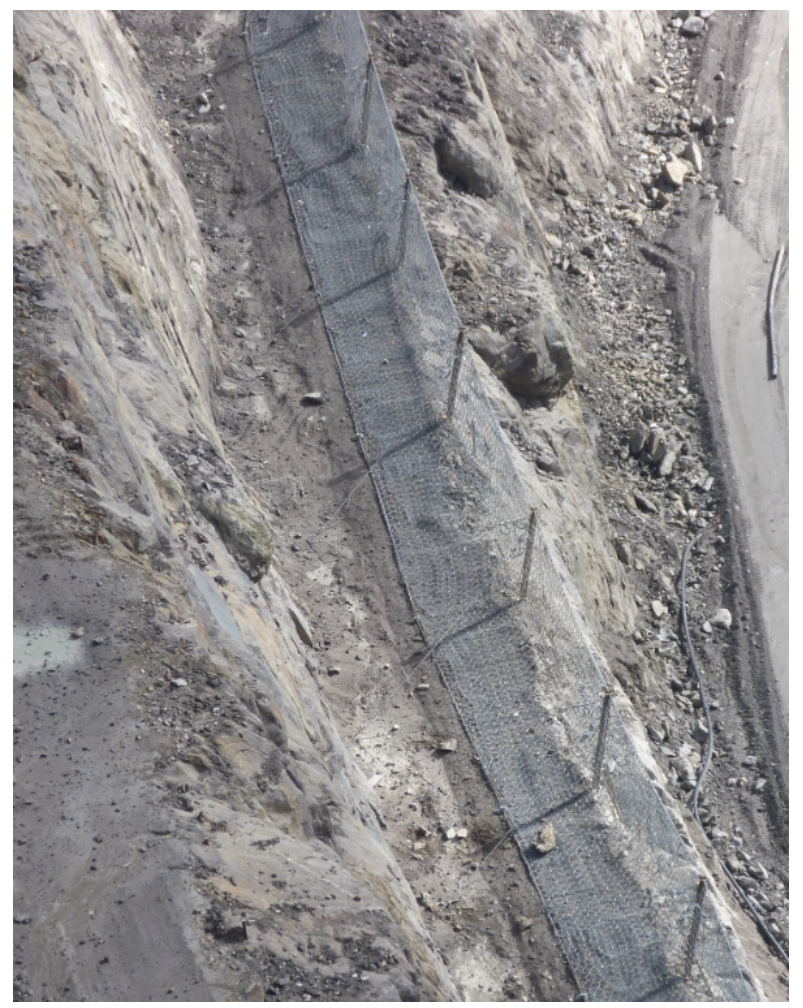

Figure 4 Geobrugg 3,000 kJ A modified barrier 
The construction of the fence required a coordinated effort between the mine planners, the production crews and the fence construction contractor. Due to risk of rockfall, as much of the construction as possible was carried out from outside a $10 \mathrm{~m}$ 'restricted zone' (within which any work was to be reduced to as short a time as practically possible). The sequencing of the mining and fence construction was as follows:

- Upon reaching the fence berm, all scaling and washing of the batter was to be completed and the floor for $30 \mathrm{~m}$ out from the toe was to be fully dozed and graded. This provided a clean working platform and the space for a subsequent trim shot in front of the fence.

- The mining production crews were then free to continue mining the main production shots in the centre of the pit.

- The shear pins, the fence post holes and the fence anchor holes were remotely drilled.

- The shear pins and fence posts were installed by a crane, located outside the restricted zone.

- Agitator trucks were used to grout the pins and posts by travelling along $12 \mathrm{~m}$ off the wall and grouting via an extended chute.

- After grouting the pins, a row of pre-split holes was drilled along the crest line and then fired 24 hours after the pin grouting had been completed.

- The fencing contractor was then mobilised and grouting of the anchors occurred. In this instance, the back anchors were quickly placed in the holes near the toe of the slope. A long poly grout line was placed into the anchor hole allowing grout mixing and pumping to occur from outside the $10 \mathrm{~m}$ restricted zone.

- The fence posts, with the support ropes and pulleys attached, were then erected; with men looping the support cables back through the anchors and then tensioning the cables. This process placed the men close to the highwall for extended periods and was the period of highest risk.

- The upper longitudinal rope was placed and tensioned and the top of the posts securely clamped.

- Bundles of Rocco ring mesh were then lifted and the support cables placed through the upper Rocco rings and pulleys; followed by a repeat with the lower cables. For the revised design, the fencing contractor was again required to work inside the restricted zone to attach the lower row of Rocco rings to the back-anchor cables.

- The Rocco ring panels were then pulled out like curtains and the panels were shackled together, always working in front of the mesh.

- The last stage of construction was to place secondary mesh from the top support rope down behind the Rocco mesh and to then clipped them together. Most of this work was carried out from elevated work platforms or from the ground outside of the mesh.

- Following the completion of the fencing, the production crews would then drill and fire the trim shot back to the pre-split.

- Production excavation of the trim shot was followed by careful mechanical scaling to ensure the shear pins and fence were not damaged. Most of this work was carried out on day shift under the direction of the geotechnical department.

This sequencing is summarised in Figure 5.

The time to design and supply these high-energy fences is typically in the order of one to two months so careful forward assessments and planning is required to allow for the least amount of mining production down time. On average, $100 \mathrm{~m}$ of fence was typically erected in about seven working days but often longer dependent on the access to the berm and delays due to the mine production schedule. 


\subsubsection{Container fence}

As the Giant Pit approached the lower levels of the cutback, the size and frequency of rockfalls on the west wall increased, with several falls in the several hundred tonne range. The reasons for the increased size was thought to be related to a steeper $60-70^{\circ}$ joint set, referred to as $\mathrm{J} 4$ joints, and the gradual dilation of the wall that had been standing for almost two years. The mine plan had the pit reaching its final depth of $360 \mathrm{~m}$ before the autumn rains in 2019. To counteract these rockfalls, the mine design over the lower $60 \mathrm{~m}$ was altered to flatten the batter slopes to $60^{\circ}$ and to leave a wider berm at the RL 908 level. Not being able to quickly order and construct a Geobrugg high-energy fence within the short time frame available, an alternative container-based fence was designed between the site staff, Mining One and Geobrugg, refer to Figure 6.

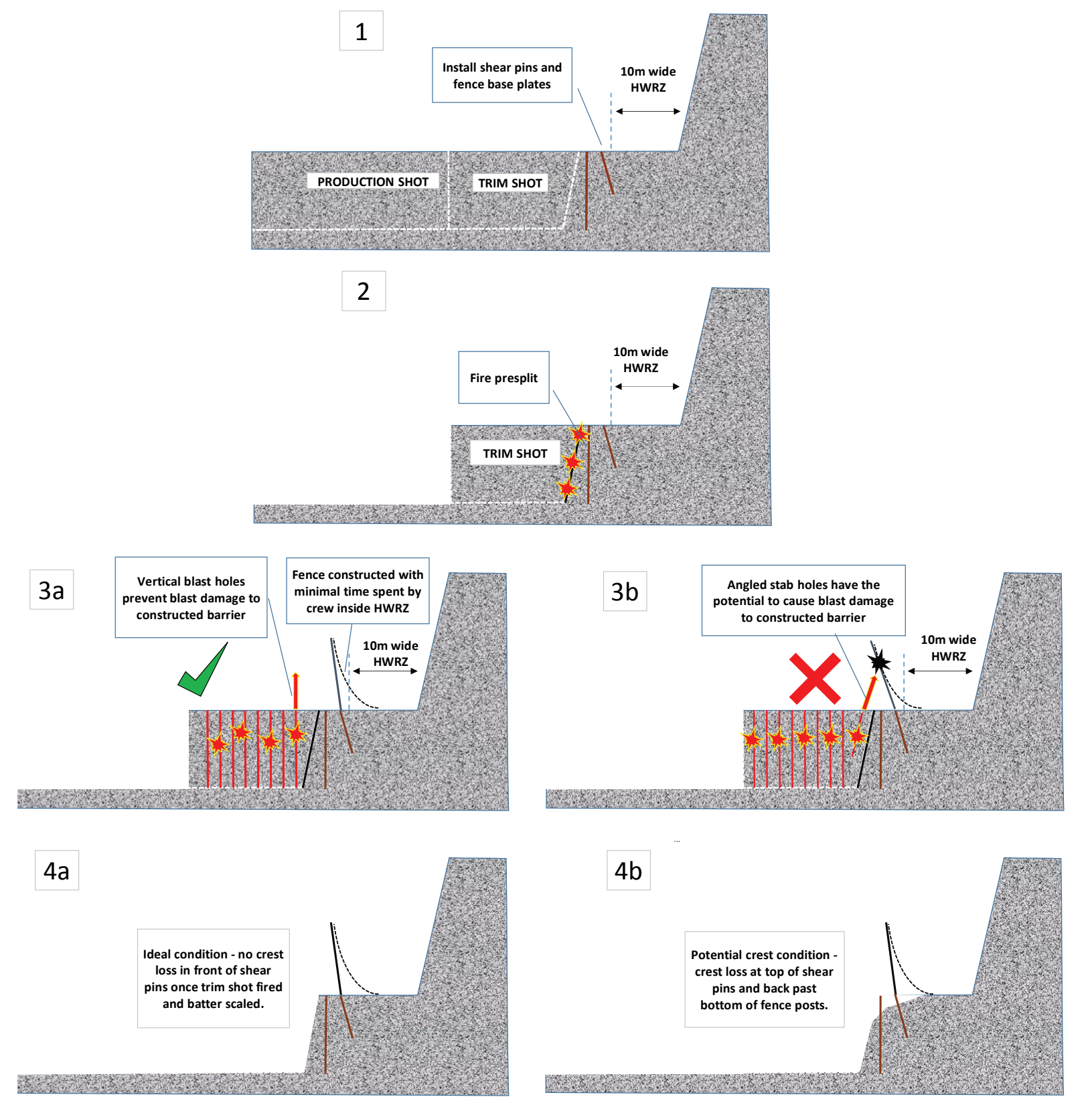

Figure 5 Rockfall barrier construction and mining sequences

Geobrugg designed a lightweight fence that was to be attached to two $6 \mathrm{~m}$ long posts cut from the shear pin materials and bolted onto the two outside edges of the container. The fence used Minax G80/4 mesh which was attached to the upper cable suspended on the front posts, while the lower end of the mesh was attached 
to the back of the container. The mesh was draped to allow for room to drop in the sand once the unit was in place. Break rings were installed with the cables to lift the design capacity to $100 \mathrm{~kJ}$.

Mining One carried out a rockfall assessment using RocFall software to determine the optimal width of the berm and location of the container fence. The RocFall assessment assumed that tabular shaped blocks of rock of various weights would originate from just below the RL 980 level. Rockfalls above that level were assumed to be retained by the high-energy rock catch fence on the RL 980 berm. There was no effective berm to retain rockfalls at the RL 944 over most of the affected area, due to a major rockfall. This meant that the design rockfall height needed to be $72 \mathrm{~m}$, as shown in Figure 6.

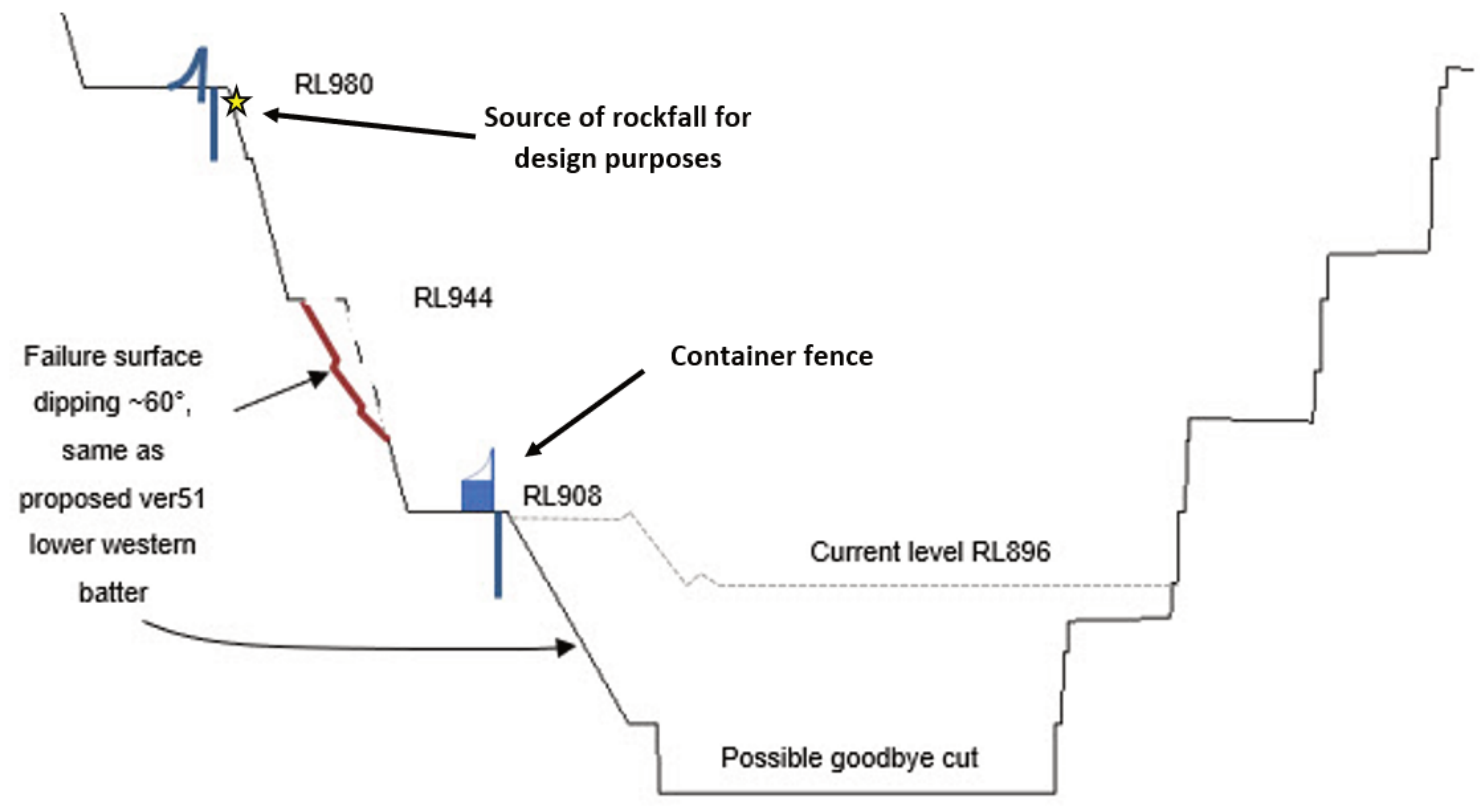

Figure 6 Container fence and rockfall simulation cross-section

RocFall simulations were calibrated to HGO's comprehensive rockfall database, by adjusting parameters that control the interaction of falling rocks with the batter face and benches. Rocscience RocFall software provides a comprehensive table of suggested parameters. It was found that parameters that were much lower than those suggested by Rocscience needed to be used to produce realistic simulations. Parameters for the rock batter and bench surface are provided in Table 1. Rock parameters are summarised in Table 2 . The shape and initial rotation of $-60^{\circ}$ were chosen to simulate tabular blocks sliding on $\mathrm{J} 4$ joints.

Table 1 Parameters for ground surfaces used in RocFall

\begin{tabular}{lllll}
\hline Material & Normal restitution & Tangential restitution & Dynamic friction & Rolling friction \\
\hline Rock & Normal distribution & Normal distribution & Normal distribution & Normal distribution \\
surface & Mean 0.45 & Mean 0.85 & Mean 0.75 & Mean 0.40 \\
& Std. dev. 0.04 & Std. dev. 0.04 & Std. dev. 0.04 & Std. dev. 0.04 \\
& Rel. min. 0.12 & Rel. min. 0.12 & Rel. min. 0.12 & Rel. min. 0.12 \\
& Rel. max. 0.12 & Rel. max. 0.12 & Rel. max. 0.12 & Rel. max. 0.12 \\
Bench & Normal distribution & Normal distribution & Normal distribution & Normal distribution \\
surface & Mean 0.20 & Mean 0.60 & Mean 0.55 & Mean 0.60 \\
& Std. dev. 0.04 & Std. dev. 0.04 & Std. dev. 0.04 & Std. dev. 0.01 \\
& Rel. min. 0.12 & Rel. min. 0.12 & Rel. min. 0.12 & Rel. min. 0.03 \\
& Rel. max. 0.12 & Rel. max. 0.12 & Rel. max. 0.12 & Rel. max. 0.03 \\
\hline
\end{tabular}


Table 2 Parameters for rocks used in RocFall

\begin{tabular}{llllll}
\hline $\begin{array}{l}\text { Number } \\
\text { of rocks }\end{array}$ & Mass $(\mathbf{k g})$ & Density $\left(\mathbf{k g} / \mathbf{m}^{\mathbf{3}}\right)$ & Shape & $\begin{array}{l}\text { Initial } \\
\text { velocity }\end{array}$ & Initial rotation (deg) \\
\hline & & & Rectangle & $\begin{array}{l}\text { (horizontal, } \\
\text { vertical, and } \\
\text { rotational) }\end{array}$ & $\begin{array}{l}\text { Rel. min. } 5 \\
\text { Rel. max. } 5\end{array}$ \\
\hline
\end{tabular}

Figure 7 shows the representation of the container fence in RocFall. The two shades of slope materials represent rock/surface interaction parameters for rock surfaces, and floors or benches.

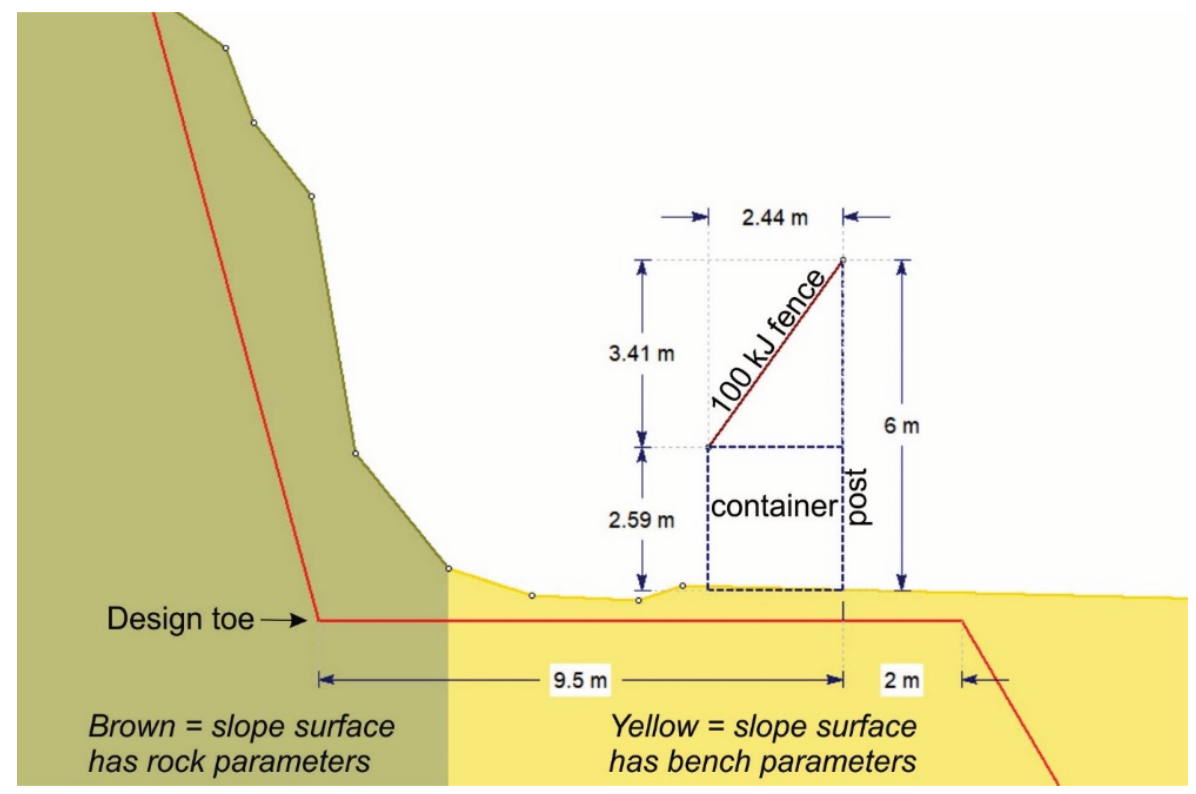

Figure 7 Arrangement of container fence relative to original design and as-mined slope

The container fence was represented in RocFall as a series of 'collectors', which are virtual boundaries that count the number of rocks falling through them. Collectors were used for the fence on the container, to record the number of rocks striking the fence and their energies of impact. Collectors were also extended above the fence, to record the number of rocks that cleared the fence. For this assessment, the containers themselves were assumed to be impenetrable.

The distance of $9.5 \mathrm{~m}$ shown in Figure 7, from the original design toe to the outer edge of the container fence, was the average distance that containers could be placed on the original design. In the analysis, this distance was then varied to determine the optimum location for the container. In the highest risk area, where the RL944 berm was lost, the outer edge of the containers to achieve the best effective results was determined to be a distance of $16 \mathrm{~m}$ from the toe. To allow for the shear pins and some crest loss, the revised crest line was placed a further $2 \mathrm{~m}$ off the container. The mine design was then altered to allow for the new container fence and to flatten the lower batters to $60^{\circ}$. The reduced batter angle of $60^{\circ}$ below the berm was adopted to reduce the risks of failures along $\mathrm{J} 4$ or $\mathrm{J} 1$ structures undermining the containers.

Due to the tight switchbacks and narrow ramp system, the base of the fence was comprised of individual $20 \mathrm{ft}$ containers rather than the longer $40 \mathrm{ft}$ containers, which could not be manoeuvred around the corners. Each container had two $2 \times 2.5 \mathrm{~m}$ holes cut in the top to allow sand to be dropped into the containers as ballast.

The preassembled fence and container units were transported into the pit on a tilt tray truck. Once in the pit, the units were lifted by forks on a front-end loader and then progressively placed from one end, working 
along the trim shot and protected by the previously installed containers. In this manner, the front-end loader was always protected by the previously placed units.

Figure 8 shows the concept of staging the container fence and its position on the berm. The containers were placed in an initial position (Figure 8a) to provide a safer working area to install the shear pins and to drill, load and fire the pre-splits. At that point in time, the containers were not filled with sand, nor were they shackled together.

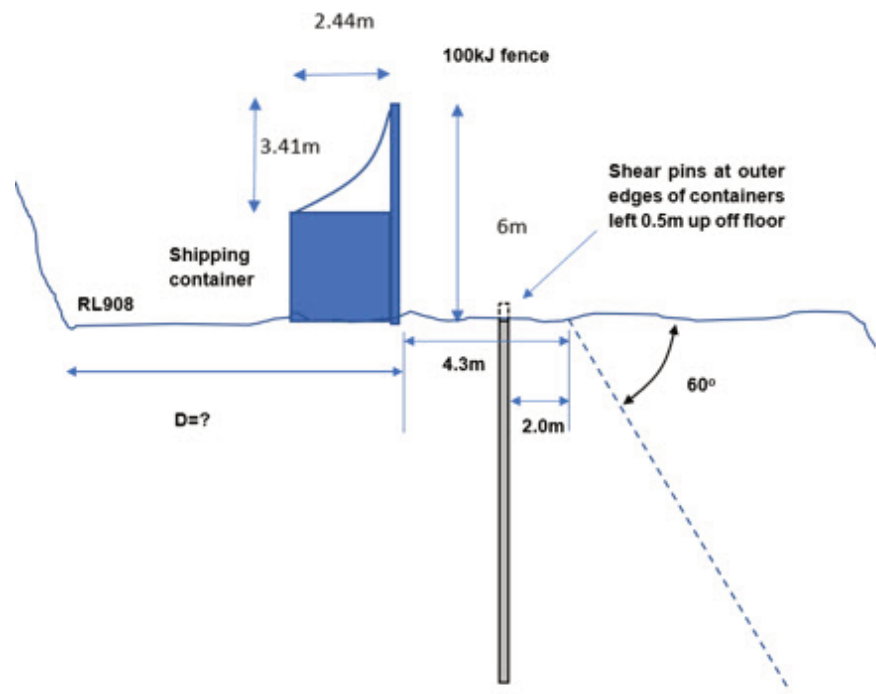

(a)

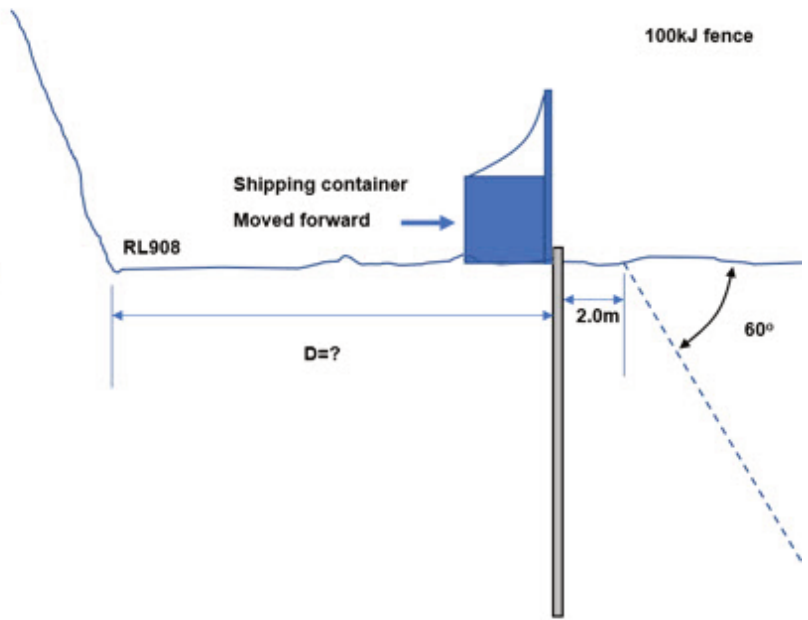

(b)

Figure 8 Container barrier concept

Once the shear pins and pre-splits were completed, the containers were manoeuvred further out to the shear pin line (Figure $8 b$ ) to increase the catch capacity. Once in their final location, the units were filled with sand then the units shackled together. The trim shot was then drilled, loaded and fired.

The materials for the container fence were procured and fully installed within three weeks of deciding to build the fence. Figure 9 shows the completed container fence after the batter below it was excavated. The $\mathrm{J} 1$ joints are evident and are effectively retained by the shear pins with the $60^{\circ}$ batter design also reducing the likelihood of undercutting by J4 joints.

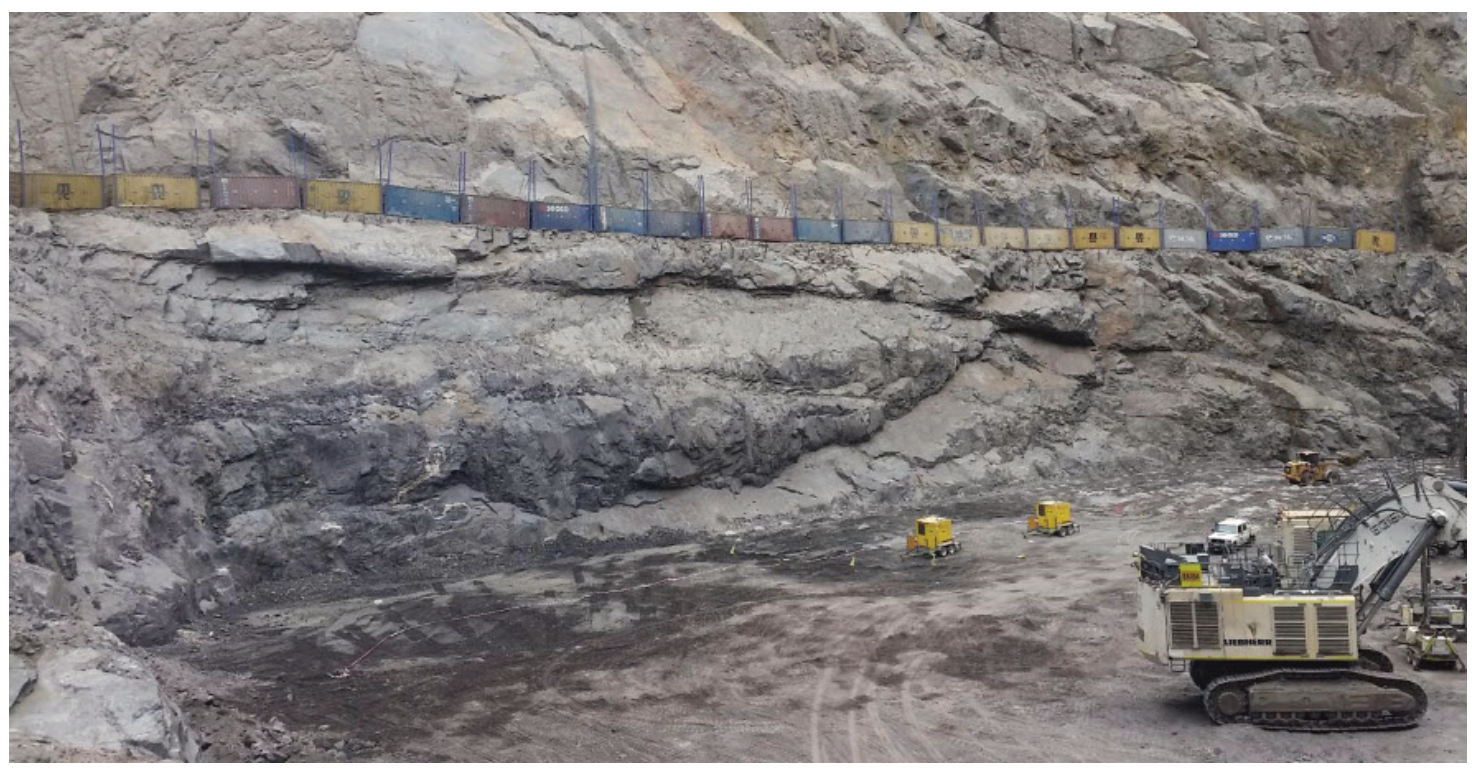

Figure 9 Completed container fence after excavating the batter below 


\subsubsection{Low energy rock catch fences}

Two Geobrugg T35 (35 kJ) type low energy rock catch fences were installed around the pit to control low energy rockfalls. In the case of the fence shown in Figure 10, the slope above the fence was a rill slope with mainly flaggy slabs of rock sliding down the slope. Occasionally, more rounded relatively lightweight rocks rolled down the slope and into the fence as can be seen in the photo. This fence was directly above the main haul road.

\subsubsection{Drape mesh installations}

Fifteen drape mesh installations were installed in a variety of locations around the pit. Along the upper pit crests, where there were weathered rock materials, the upper $12-15 \mathrm{~m}$ of slope was laid back to $50^{\circ}$. Over approximately $50 \%$ of these slopes, lightweight Deltax G80/2 mesh was draped over the crest to prevent rilling of small rock material (typically $<20 \mathrm{~kg}$, but occasionally in the order of $300 \mathrm{~kg}$ ) during rain events. Where larger blocks were identified as being potentially unstable, Minax G80/3 mesh was used. These installations on the $50^{\circ}$ batters apply normal forces to the rock surfaces around the crest areas preventing rocks from displacing in these areas.

Two methods of anchoring were used (Figure 11). Along the pit crests, $2 \mathrm{~m}$ long $25 \mathrm{~mm} \mathrm{GIWI}{ }^{\circledR}$ bars were grouted into the ground to anchor the upper supporting cable. Along the lower east wall ramp areas, windrows of loose rock were left as safety windrows preventing trucks from driving off the edge of the ramp. In such conditions, rock materials from the windrows often loosened and had the potential to fall down the underlying vertical rock batters. Where meshing of these areas was required, concrete-filled, 200 litre drums were placed into the safety windrows and the upper cable was shackled to wire rope loops set into the concrete.

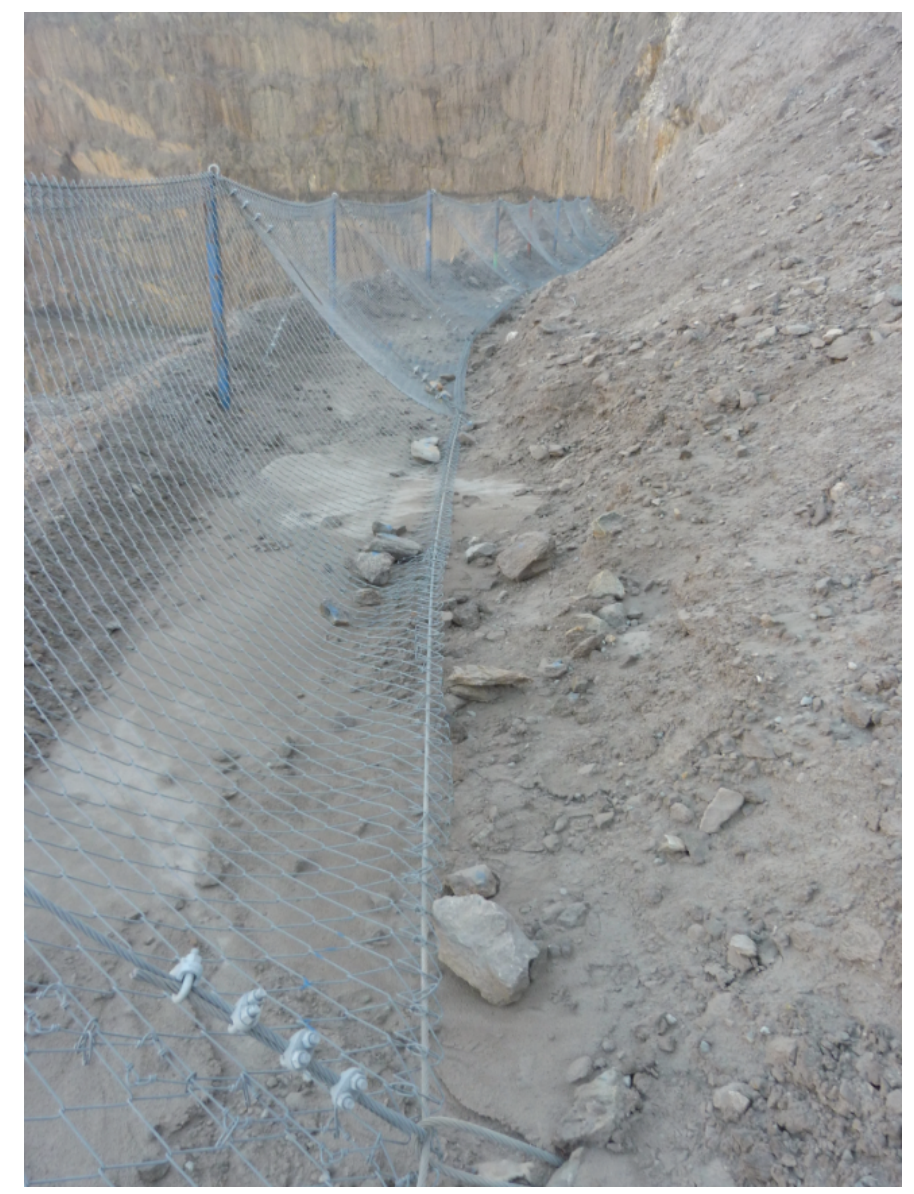

Figure 10 East wall T35 fence 


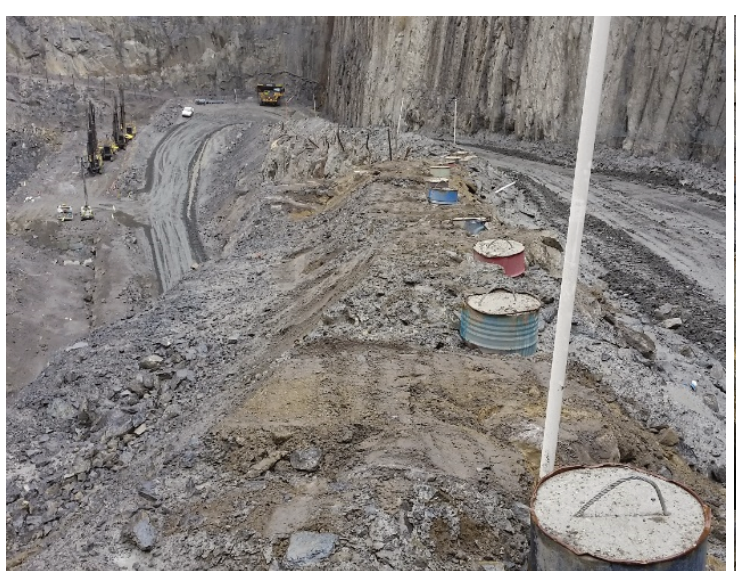

(a)

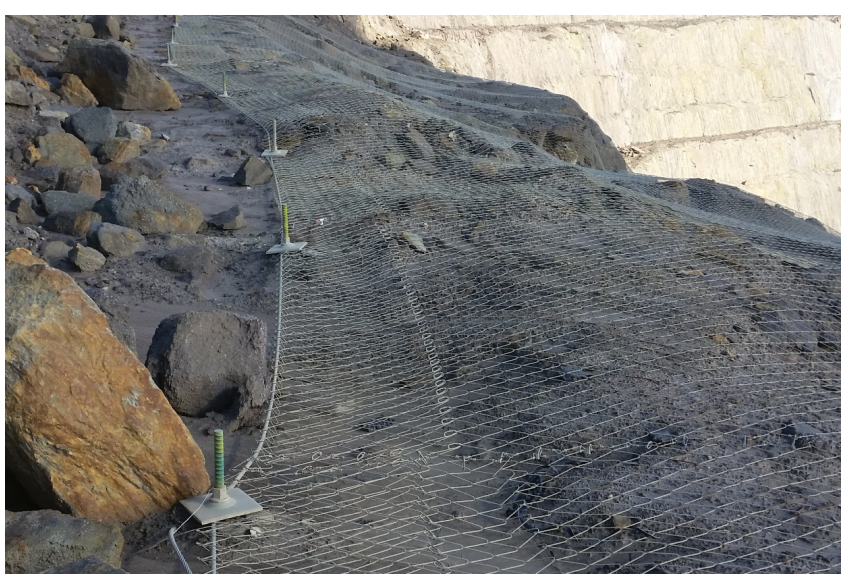

(b)

Figure 11 Drape mesh anchoring systems

In most of the mesh installations on vertical batters, there were often small overhangs from which additional rocks could fall-out. On these batters, there were often normal force components along the upper windrow areas but not on the lower areas. In such situations, the mesh is designed to 'control' the block of rock as it ravels down behind the mesh. The design of these mesh installations was determined by the puncturing and shearing resistance of a particular mesh type.

Once the anchoring systems were in place, the rolls of mesh were attached to the upper support cable with small overlaps of the rolls. The rolls were then pushed over the crest and they unravelled by gravity. The rope specialist contractor then rappelled over the edge, straightening out the rolls and clipping them together. As per Geobrugg's design, the lower ends of the mesh were for the most part anchored via a lower cable. For various reasons, some of the installations did not initially get lower anchors. Quite surprisingly two of these non-anchored drape meshes were blown around by high winds; with large sections of the lower corner blown back onto the main mesh, leaving sections of the batter fully exposed. Remedial works were required to repair these mesh areas.

\subsection{Attenuator fences}

Several attenuator fences were installed where extensive berm losses occurred. These attenuators are designed to 'capture' blocks of rock falling from the batters above the lost berms and to then 'control' those blocks, as the rockfalls down behind the lower mesh. The upper mesh is typically designed for larger impact loading. The attenuator shown in Figure 12 was designed to control $2.4 \mathrm{t}$ blocks falling from up to $36 \mathrm{~m}$ above the fence. The energies calculated from RocFall simulations were typically in the range of 500-660 kJ, with outliers of up to 800-900 kJ. The upper mesh designed to take the initial impact of the fall was Tecco 65/4 mesh, while the lower control zone was comprised of Minax 80/3 mesh.

Prior to installing the attenuator, the batters above were thoroughly scaled over two days to remove as much loose material as possible. The work on this fence then took an additional eight days with the rope specialist working 10-hour day shifts. Trucking continued on night shifts and for most of the day shifts as an offramp was constructed just above the work area. The ramp directly below the work area was then windrowed off allowing protection to the crews and crane that took up the full width of the lower ramp. 


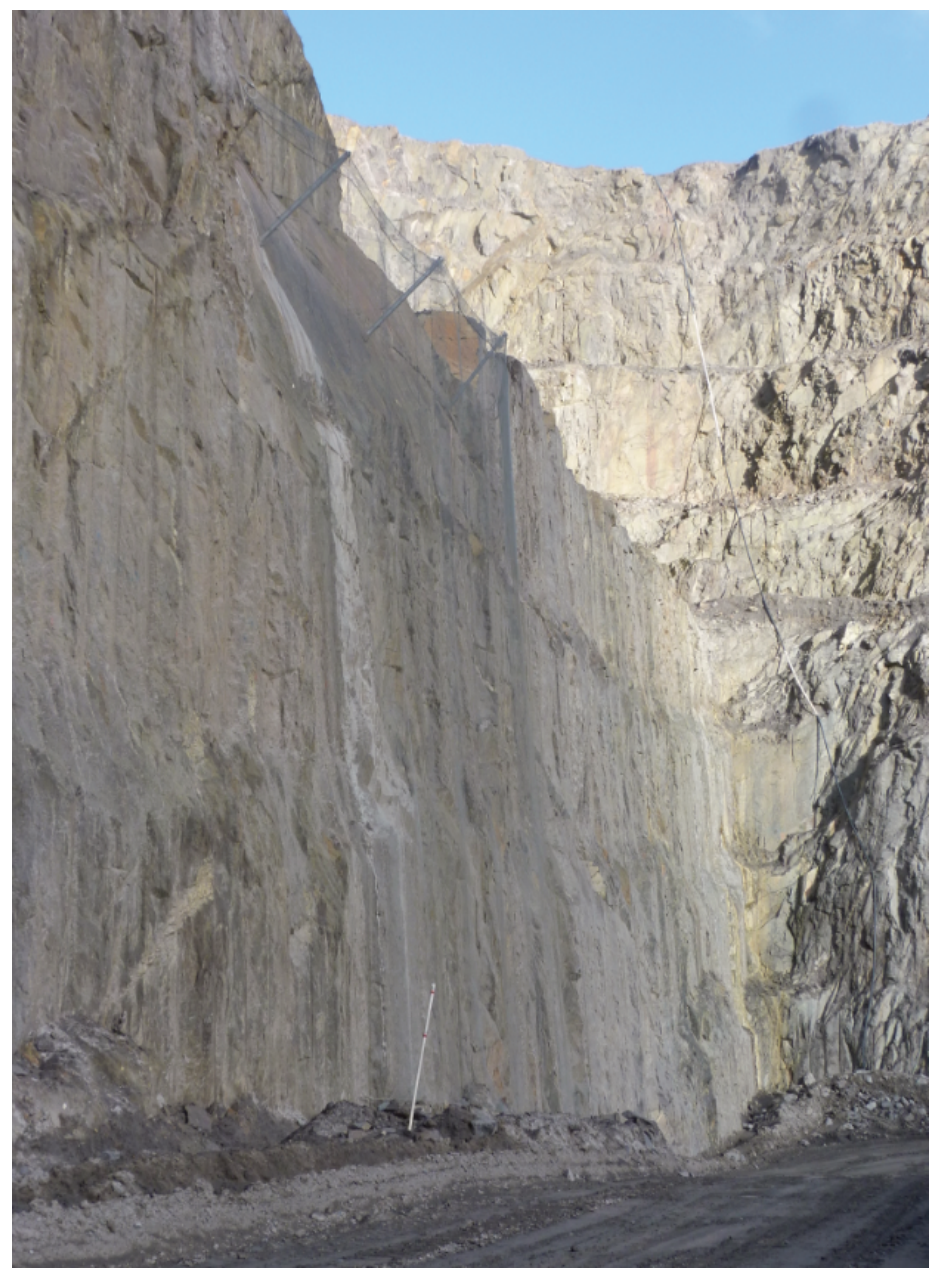

Figure 12 Attenuator fence

\subsection{Cable strap/mesh installations}

Where large potentially unstable blocks were identified and could be reached by cranes, cable strapping was employed to prevent such blocks from working loose and cascading down the slope. One such block is shown in Figure 13. This block was directly above the attenuator fence of Figure 12. During the initial scaling process, before the construction of the attenuator, the block had been noted but it appeared to be stable. Several months later during routine batter inspections (using binoculars), small cracks were identified around the block. A drone was flown over the area and then a rope specialist rappelled down to inspect the area and confirmed the recent movement. In such cases, the block would normally have been scaled or air bagged off the slope. In this case, the attenuator fence was directly below the block. Due to the size of the block, the attenuator would likely have been badly damaged or possibly destroyed if the block was scaled off the batter. Upon confirming the movement, a cable strapping/mesh reinforcement system was designed by Geobrugg, which also mitigated the need to work directly below the potentially unstable block. The system was installed by drilling anchors from a crane basket on either side of the block, with Spider mesh then hung off the upper cable and draped down over the block. Additional cables were then strung over the mesh and tension across the block as can be seen in Figure 13. 


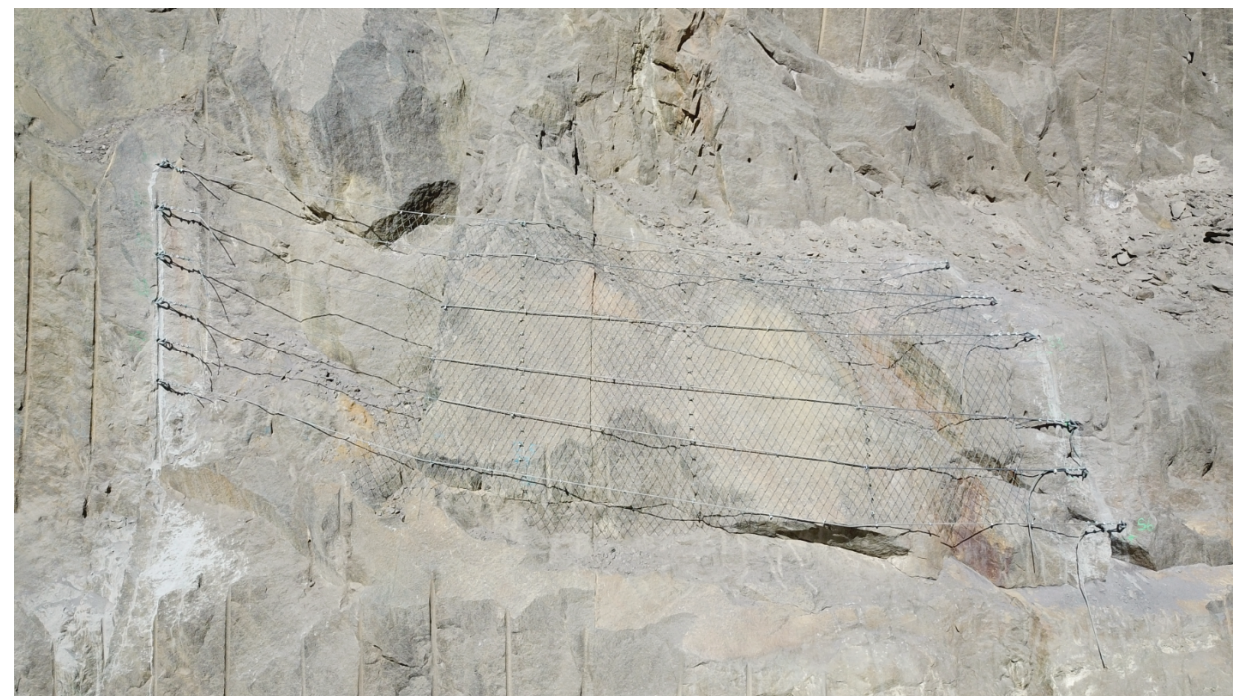

Figure 13 Cable strap/mesh installation

Most of this work was carried out from the dog box lowered by the crane placed on the upper crest over three days. As the crane was out of the way and the attenuator was in place to control any small blocks that may have become dislodged, trucking continued directly below as the works were undertaken.

\section{Costs}

The supply and install costings for the majority of the rock support and scaling that occurred in the Giant Pit are shown in Table 3. One should note that the shear pin costs do not include the drilling costs as they were absorbed by the drill and blast cost centre and were not differentiated until late in the program.

The drape mesh costs varied significantly due to the types of mesh used and to the initial installations being carried out by an interstate contractor. Two of the earlier installations were in the order of AUD 40/ $\mathrm{m}^{2}$. Another significant cost increase occurred when cranes were required.

Table 3 Rock support costs

\begin{tabular}{lllllll}
\hline & Support type & Quantity & & Cost (AUD) & Unit cost (AUD) & \\
\hline A & Shear pins & 2,141 & No. & $2,324,445$ & 1,096 & $/ \mathrm{pin}$ \\
B & Shotcrete & 690 & $\mathrm{~m}^{2}$ & 43,545 & 63 & $/ \mathrm{m}^{2}$ \\
C & Drape mesh & 37,960 & $\mathrm{~m}^{2}$ & 758,655 & 20 & $/ \mathrm{m}^{2}$ \\
D & Attenuator fences & 5,700 & $\mathrm{~m}^{2}$ & 204,688 & 36 & $/ \mathrm{m}^{2}$ \\
E & Rock Catch fences & & & & & \\
& RL 1088 RXE 3000 A + repairs & 293 & $\mathrm{~m}$ & 791,338 & 2,701 & $\mathrm{~m}$ \\
& RL 1054 RXE 3000 A & 44 & $\mathrm{~m}$ & 106,404 & 2,420 & $\mathrm{~m}$ \\
& RL 980 RXE 3000 A (mod) & 500 & $\mathrm{~m}$ & $1,318,644$ & 2,637 & $/ \mathrm{m}$ \\
& RL908 container fence & 160 & $\mathrm{~m}$ & 23,680 & 1,442 & $\mathrm{~m}$ \\
& T35 fence & 296 & $\mathrm{~m}$ & 95,028 & 321 & $\mathrm{~m}$ \\
F & Cable strapping and mesh & - & & 43,475 & - & \\
G & Scaling & - & & 45,771 & - & \\
& & Total: & & $5,755,673$ & & \\
\hline
\end{tabular}

Note: Shear pin costs do not include drilling costs 
The high-energy rock catch fence costs show that the RXE $3000 \mathrm{~A}$ fence typically cost in the order of AUD $2,400 / \mathrm{m}$. However, if there was either minor or major crest losses and repairs were required the costs rose significantly (AUD 2,700/m) to be above those of the modified barrier, with the mesh placed behind the posts and anchored back onto the berm (AUD 2,640/m). The repair costs did not take into account the losses in production due to the delays in carrying out the extra work. In some instances that may not be a major issue but in a small pit the delays can be quite significant.

Although the container fence is significantly cheaper, it required a 15-18 m wide berm compared to the other fences, which were placed on $13 \mathrm{~m}$ wide berms. This would likely greatly add to the overall mine stripping ratio if several of these berms were required. The main advantage of the container fence was its rapid design and deployment. This occurred at a crucial time-late in the mine life-when a fence could not have been procured in time before autumn rainfall, which would greatly increase the risk of rockfalls.

The steep-walled design, with its shear pinning, was applied mainly over the western and south-western walls in the GDM1 geotechnical domain. Steepening of those walls from 45 to $57^{\circ}$ in that domain saved over $5.5 \mathrm{Mm}^{3}$ of waste rock movement. At a cost of approximately $\$ 15 / \mathrm{bcm}$ the cost saving of over $\$ 82 \mathrm{M}$ greatly offset the $\$ 6 \mathrm{M}$ in rockfall remediation costs.

\section{$7 \quad$ Effectiveness}

The effectiveness of the shear pinning can be seen in Figure 14. The left-hand side of the photo was a previous remnant wall from the Spitfire Pit, where no shear pins had been utilised. Very few portions of those berms were retained. In contrast, the centre and right-hand side of the photo, where shear pins were installed showed greatly improved berm retention. This was not always the case. A $160 \mathrm{~m}$ long attenuator fence was required on the RL 1154 level of the northwest wall after a trim shot was initiated and sequentially fired in the wrong direction. This resulted in gases entering a long continuous discontinuity and lifting the complete berm off the underlying discontinuity.

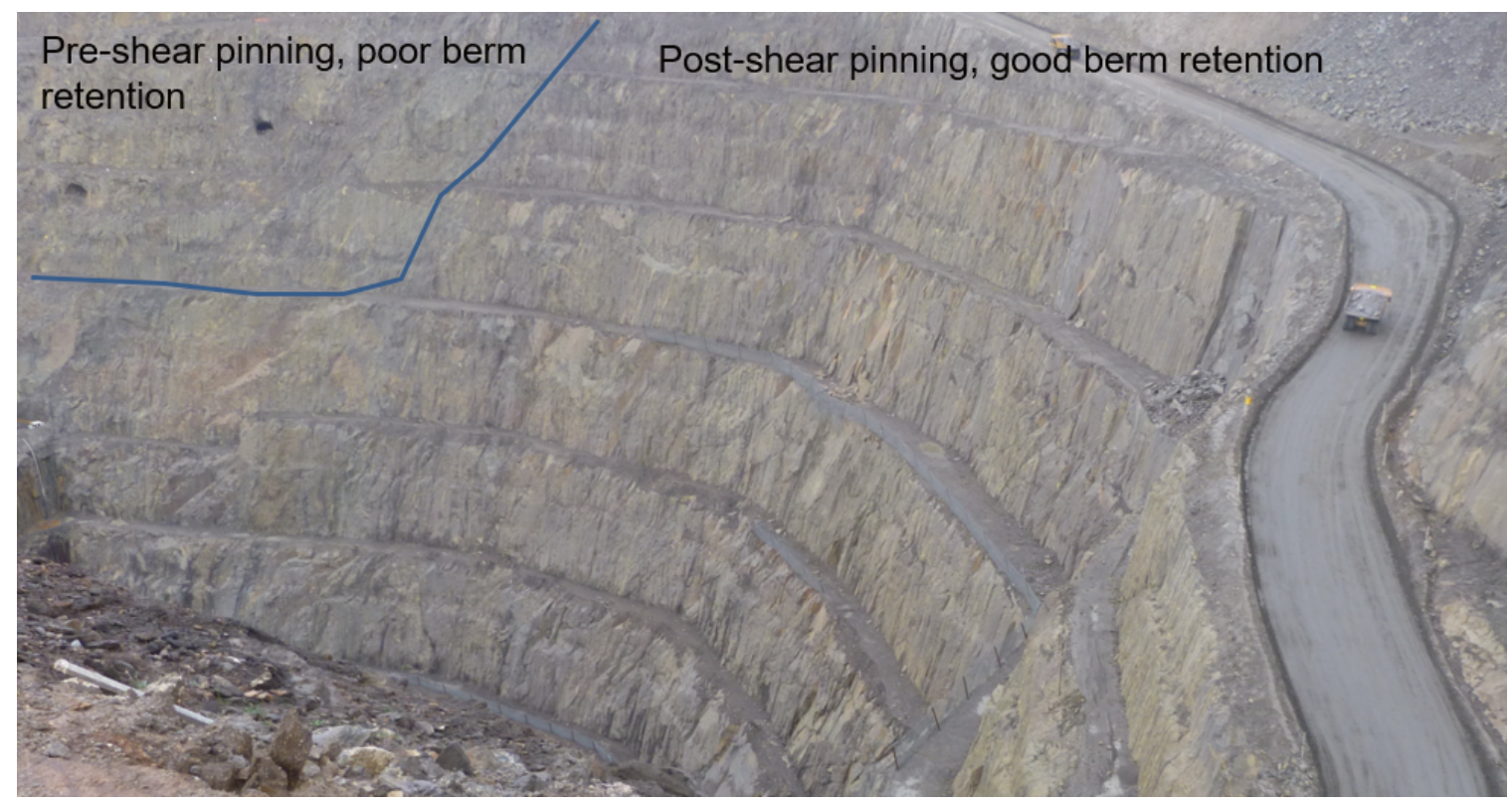

Figure 14 Southern and western walls of Giant Pit 
Examples of rocks controlled by the drape mesh can be seen in Figure 15.

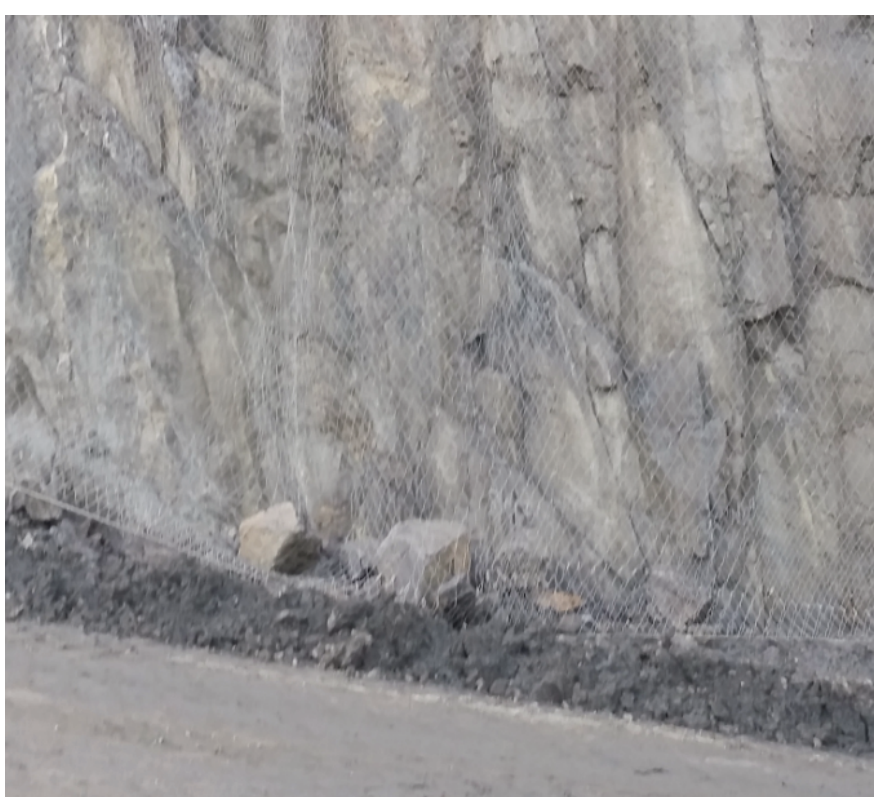

(a)

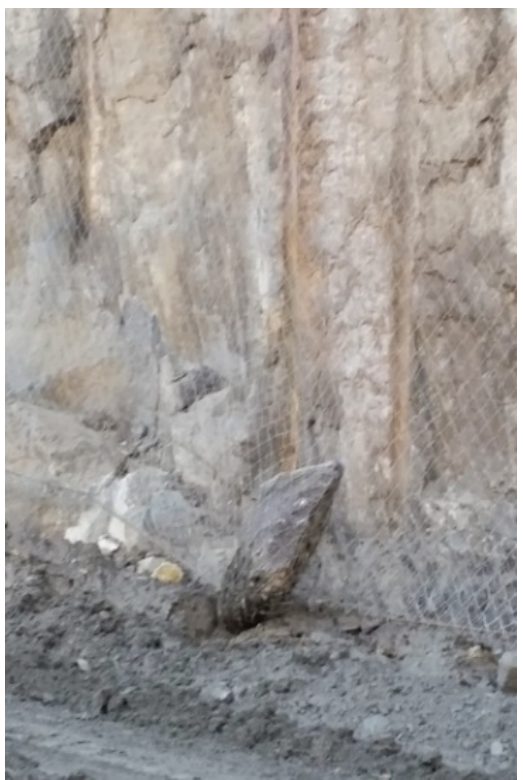

(b)

Figure 15 Drape mesh rockfall control

Examples of the smaller rocks retained by the T50 low energy fence can be seen in Figure 10; while a $5 \mathrm{t}$ rock was restrained by the 3,000 kJ fence in Figure 16.

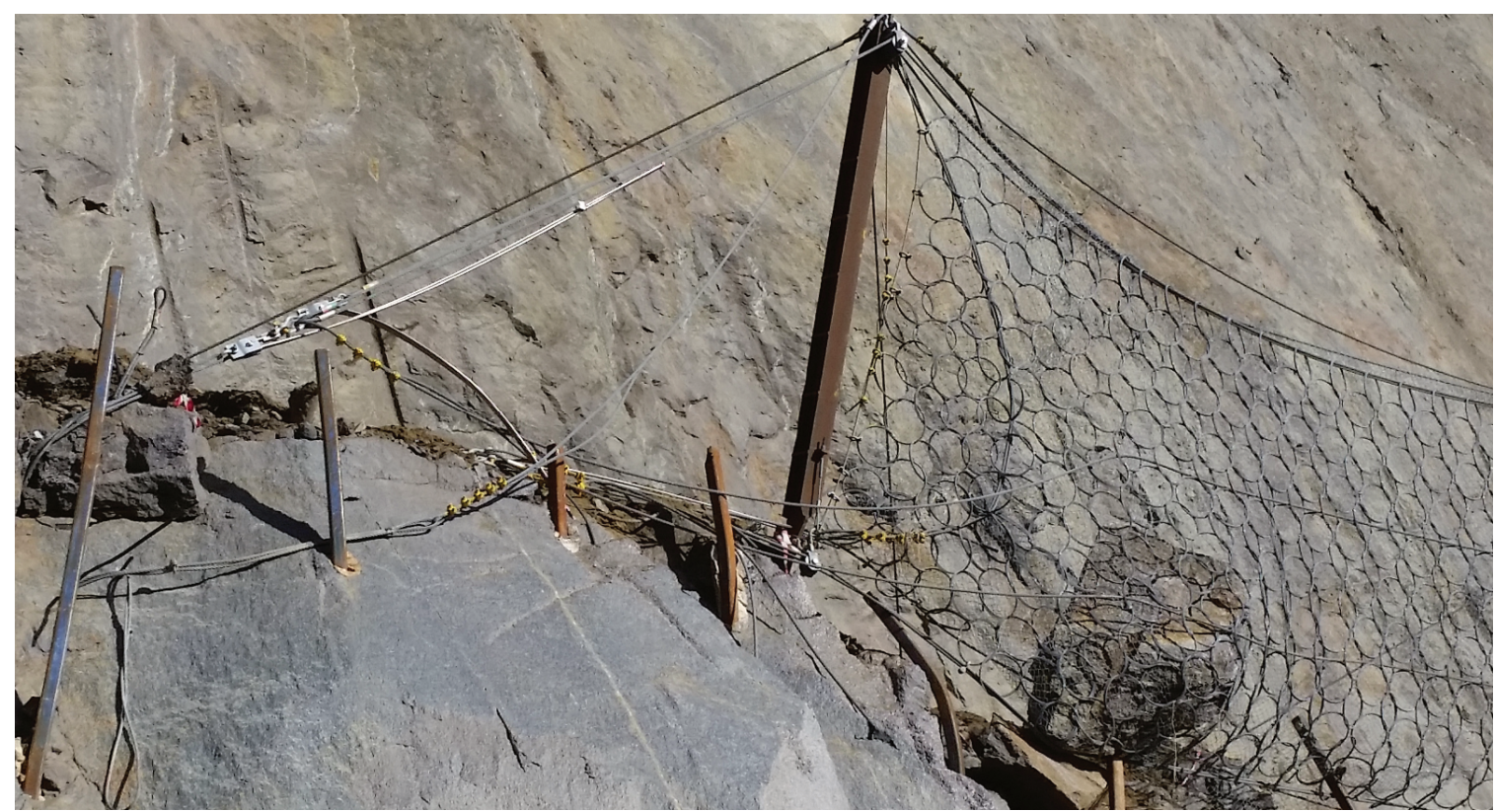

Figure 16 Five-tonne block retained by RL1052 RXE 3000 A rock catch fence

The container fence also proved to be very effective, as can be seen in Figure 17, where two major sized blocks from rockfall RF872 are lodged in one container. For a further discussion of the detection of this rockfall, refer to Hutchison \& Chambers (2020). 


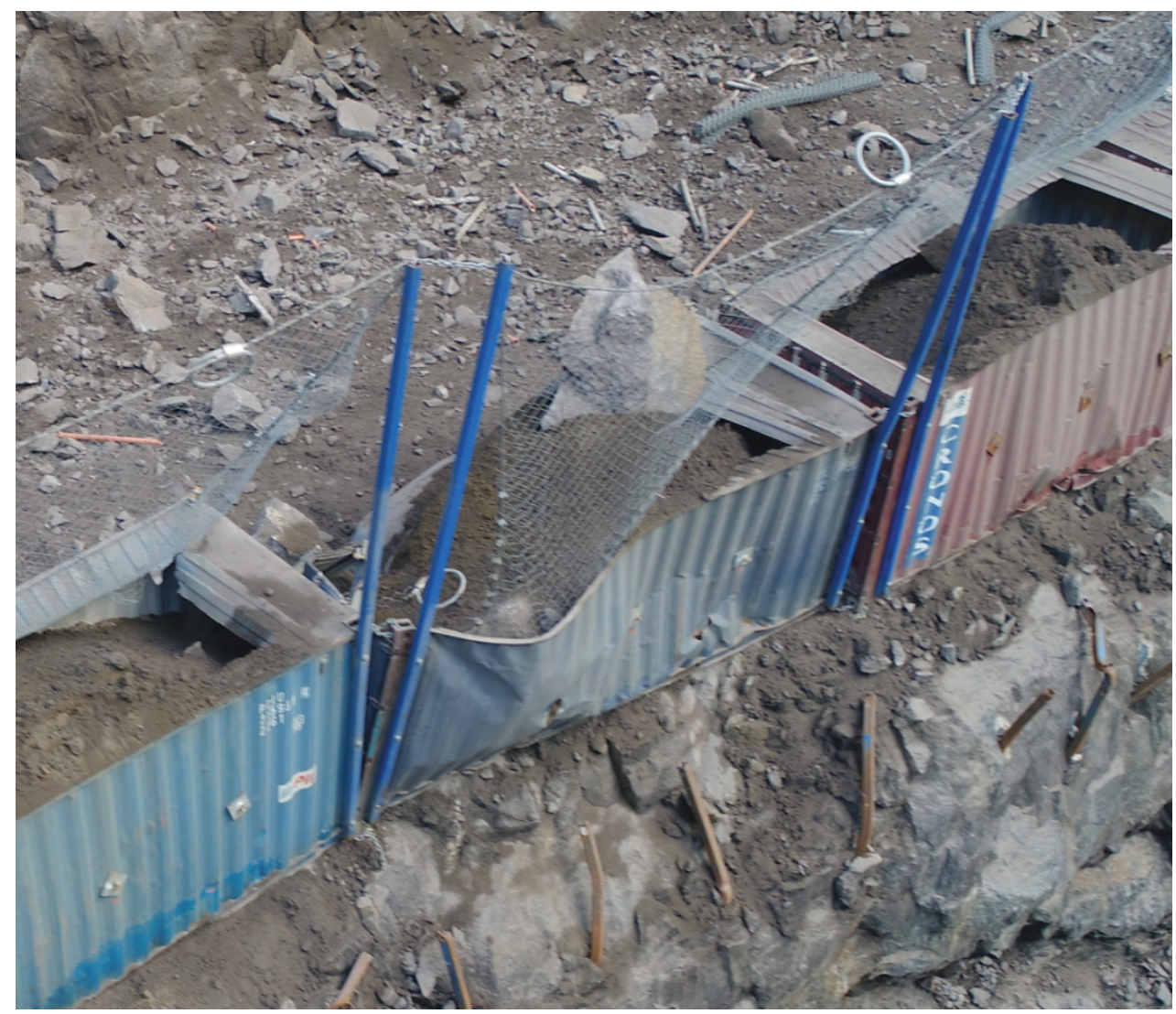

Figure 17 Container fence effectiveness

\section{Summary}

This paper provides a case history of how rock support and engineered structures can provide effective solutions to reduce the risks from rockfall. The shear pins not only provided improved rock catchment capabilities but more importantly allowed the steep wall design to be implemented. Steepening of the west wall from 45 to $57^{\circ}$ saved over $5.5 \mathrm{Mm}^{3}$ of waste rock movement within the main geotechnical domain that the steep-walled design was applied. The additional ore revenue and savings on waste movement easily paid for the costs of the rockfall mitigation structures.

It must be noted however that the design capacities of these structures can easily be exceeded by larger rockfalls and slips. At Kanmantoo, the pit production had to be stopped with only two shifts of production remaining in the pit when the onset of autumn rains and two subsequent large rockslides from $100 \mathrm{~m}$ above the pit floor made conditions unsafe. The two rockfalls, RF872 (Figures 17 and 19) and RF879 (Figures 20 and 21 ) showed what can happen when design capacities are exceeded.

In the case of rockfall RF872, the RL988 berm and rock catch fence retained the majority of the 2,464 $t$ rockfall, but as can be seen in Figure 18 the rock catch fence was effectively destroyed. Three large blocks made their way down to the RL908 berm and container fence. One block initially hit the berm and careened into the side of the container, without displacing it. The other two blocks landed in/on another container, as shown in Figure 17. A few small blocks of rock ( $<100 \mathrm{~kg}$ each) flew over the container fence and came to rest amongst parked up equipment on the pit floor. 


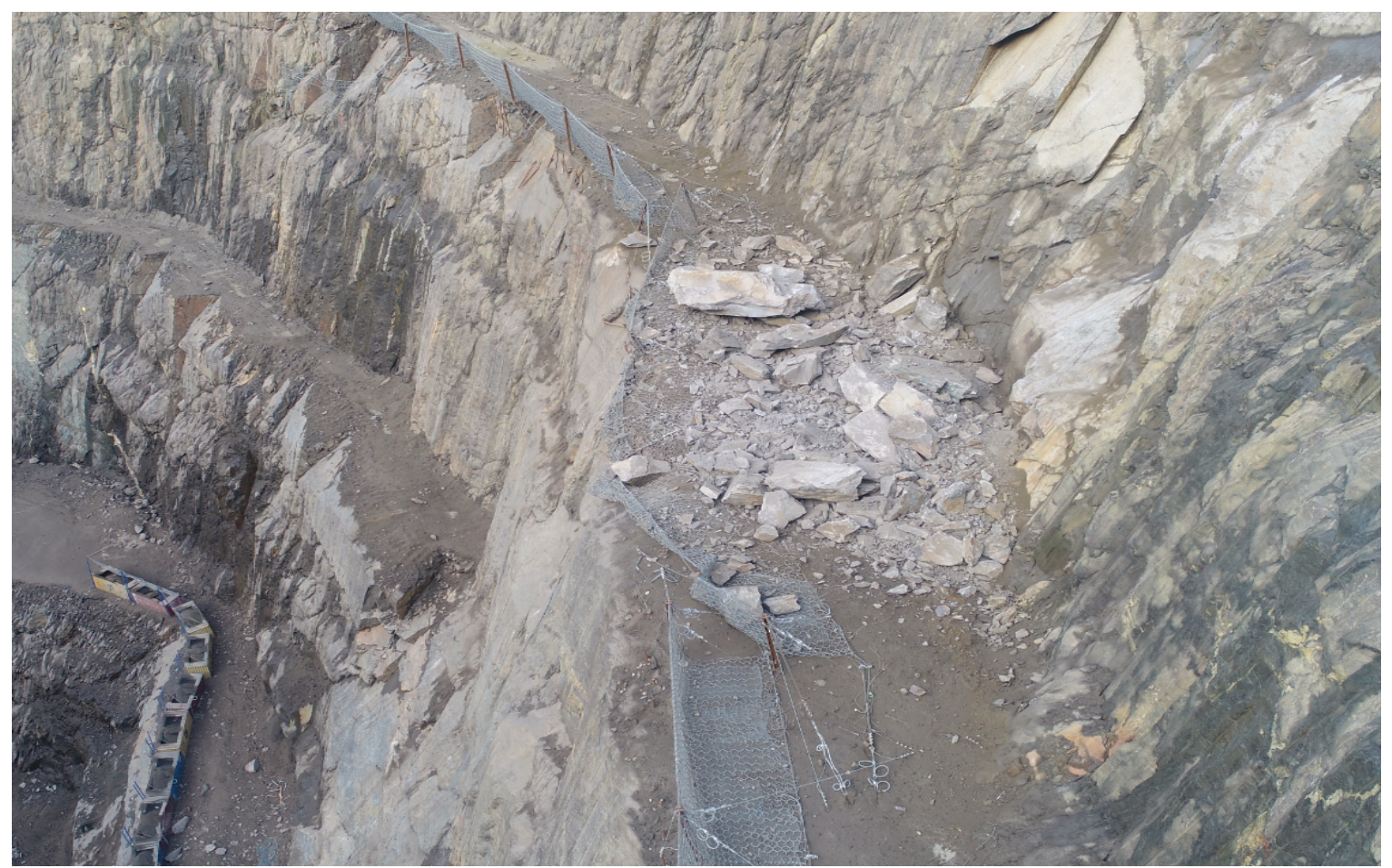

Figure 18 Rockfall 872

Rockfall RF 879 was comprised of 1,250 t of rock material. The fall was instigated by heavy rainfall and occurred from $100 \mathrm{~m}$ above the RL908 berm. The source was a shear pinned crest that had initially been supported by shear pins 20 months before the failure. The RL988 fence under this rockfall was also destroyed (Figure 19), as was the container fence (Figure 20) which was hit by several large blocks up to $16 \mathrm{t}$. In this case, several larger blocks, in the order of up to $5 \mathrm{t}$, reached the floor.

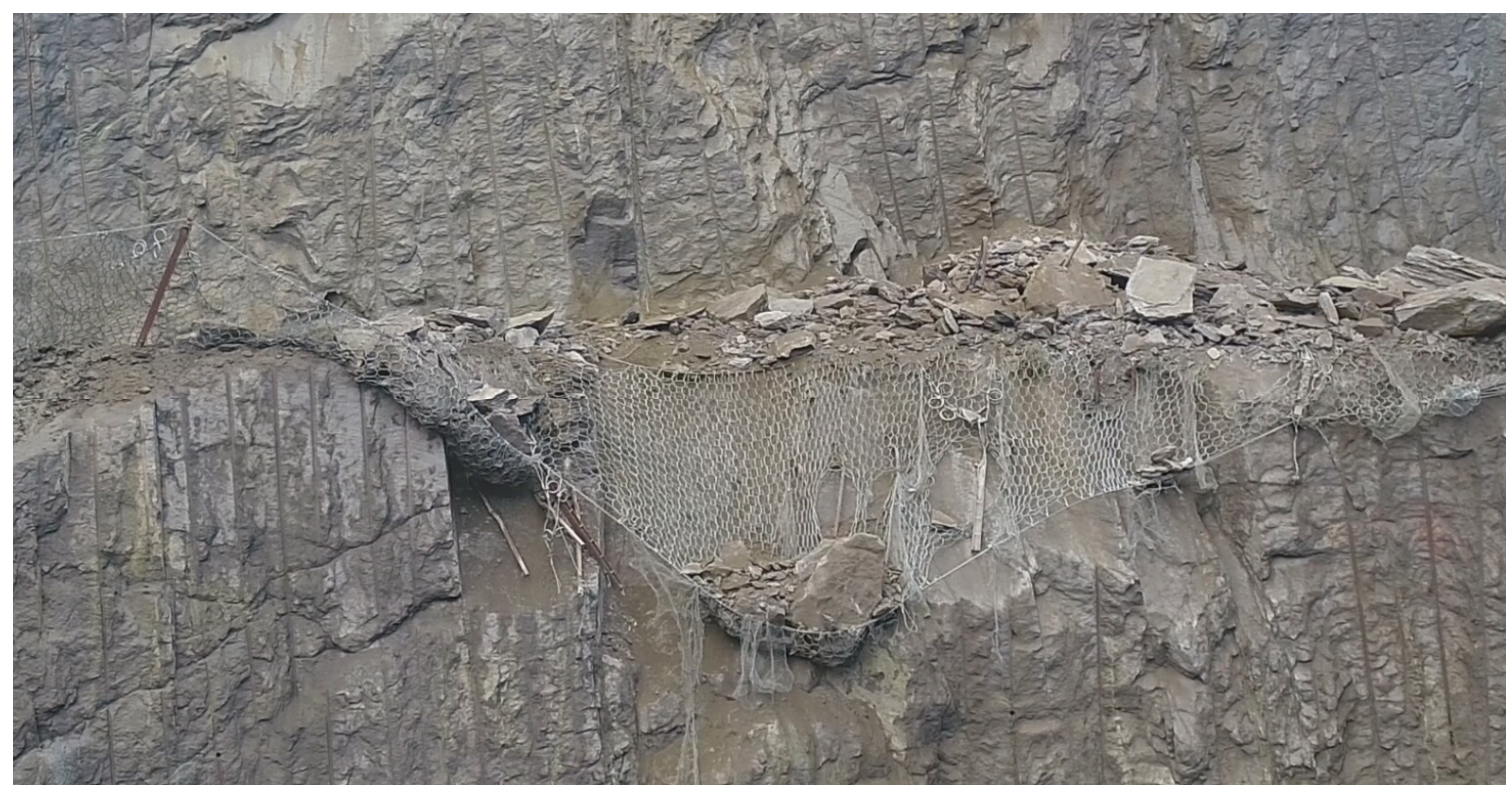

Figure 19 Rockfall RF879 - destruction of RL988 rock catch fence 


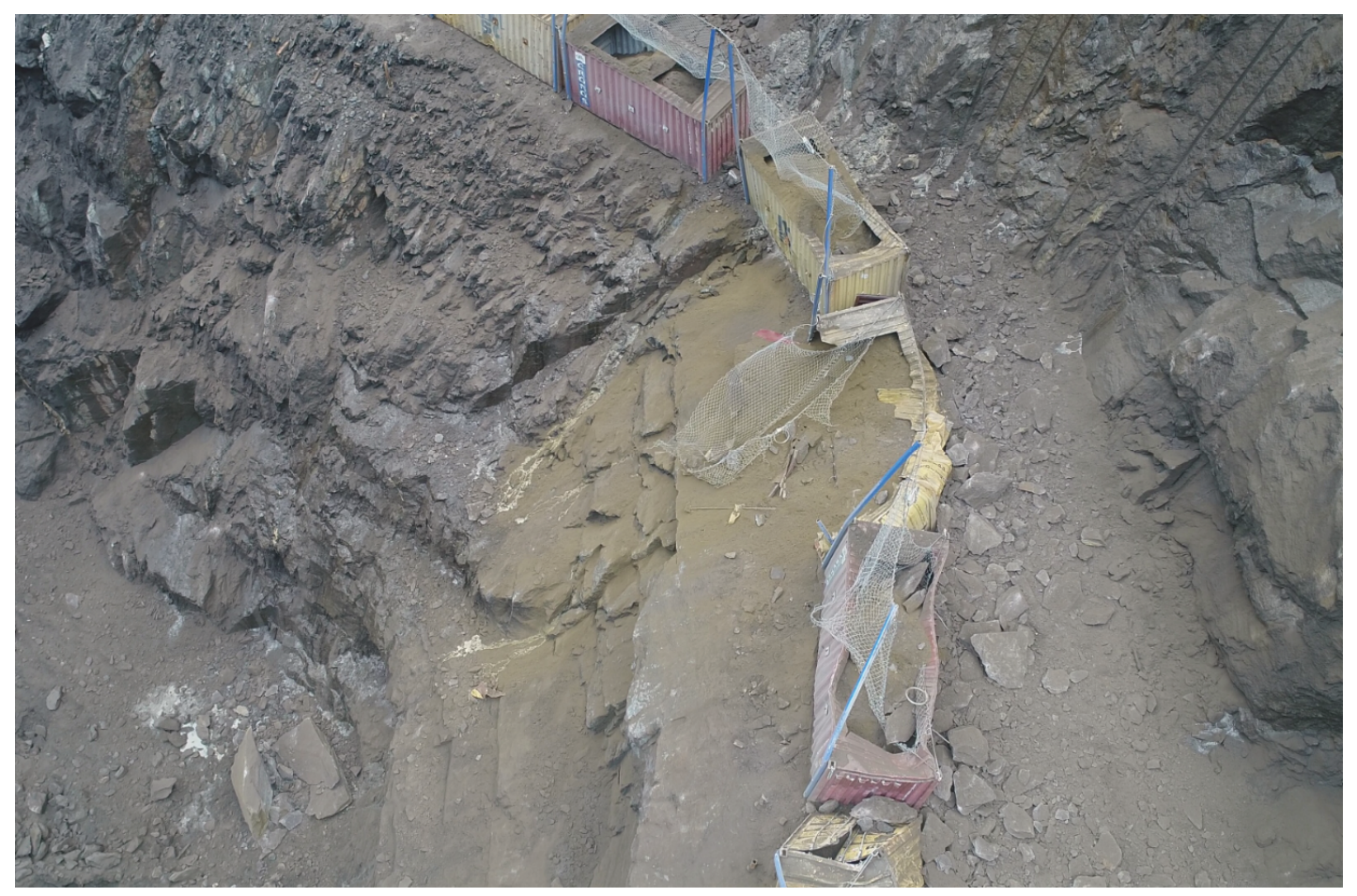

Figure 20 Rockfall RF879 - destruction of RL908 container fence

Although the two high-energy fences were 'destroyed', they and the berms, were effective in controlling over $98 \%$ of the rockslide material, with only four large blocks reaching the pit floor. Due to the rain and the known increased rockfall risks, all production had ceased and the pit had been abandoned on the days before the two rockslides, so no one was put at risk.

\section{Conclusion}

The use of shear pins and various rockfall control structures allowed HGO to implement a very aggressive steep-walled design of their recently completed Giant Pit. The costs described in this paper were easily offset by the revenue generated by the increased ore supply and savings in less waste rock movement. If embarking on the use of the control measures, such as those implemented at Kanmantoo, it is very important to fully understand the potential rockfall risks and input parameters needed to design appropriate rockfall management solutions.

\section{Acknowledgement}

The authors thank HGO for allowing this paper to be published and to Retaining Wall Solutions who carried out the majority of the construction of these engineering structures.

\section{References}

Hutchison, BJ, Chambers, J, Macqueen, G, Salas, E \& Huang, N 2015, 'The use of rockfall statistics in managing small rockfalls in two Australian open pit mines', Proceedings of the 2015 International Symposium on Slope Stability in Open Pit Mining and Civil Engineering, The Southern African Institute of Mining and Metallurgy, Johannesburg.

Hutchison, BJ, Chambers, J, Gannon, S \& Oko-oboh, D 2017, 'Case study of joint structure and the design and performance of open pit walls at the Kanmantoo Copper Mine', Proceedings of the Tenth International Mining Geology Conference, The Australasian Institute of Mining and Metallurgy, Melbourne, pp. 355-364.

Hutchison, BJ \& Chambers, J 2020, 'Monitoring of structurally controlled deformations at the Kanmantoo Copper Mine', in PM Dight (ed.), Proceedings of the 2020 International Symposium on Slope Stability in Open Pit Mining and Civil Engineering, Australian Centre for Geomechanics, Perth, pp. 1495-1506.

Rocscience 2018, RocFall, version 6.011, computer software, Toronto, https://www.rockscience.com 